Tertullian has been categorized as an African. The implication, conversely, is that Tertullian has simultaneously been de-classified; it is suggested here that the categories of "Roman" and "African" - to name two - should be destabilized in order to allow for more complexity and fluidity when interpreting Tertullian's writings, and any classification or identification of Tertullian should be qualified.

In conclusion a few words need to be said about the implications of this study for Patristics more generally. As stated inititally, Tertullian is in one sense a case study for a broader question, that of identity theory. The methods and theories applied in this study could also be applied to other Christian writers, especially others from North Africa (e.g. Minucius Felix, Arnobius, etc.; see above, section 2.4.1), which would allow for further discussions of early Christian practice and teachings. By incorporating Social Anthropology, Patristic scholars would be better equipped to avoid the ethnocentric tendencies present in any endeavor; moreover, this approach would compliment the aim of historical theologians who wish to avoid anachronism. By allowing the anti-essentialist approach of recent anthropological theorists traditional categories such as "religion," "economics" and "politics" can be unbounded, destabilized and further explored, which would permit scholars to avoid the reifying tendencies of certain dichotomous labels, such as "orthodox"/"heretic" and "Western"/ "Eastern." This approach, moreover, would sanction scholars to contextualize Christian sources in an attempt to attain a more emic perspective. While historical theologians may desire something analogous to what anthropologists call a phenomenological approach, that is, the quest for universally applicable Christian principles, practices and/or doctrines (see chapter one), caution must be used so as not to impose anachronistic, ethnocentric, or essentialist constraints and constructs on the writings and contexts of the early Christians. While this project has used theory from Social Anthropology and avoided direct comparison with modern ethnographies - for modern ethnographies can never fill in "blanks" or "gaps" in ancient history, as if some current people group are still "primitive" and are more comparable to ancient Christians or Romans than are western Christians or societies, perhaps one comparison will help solidify the above rereading of Tertullian by juxtaposing his contextualized theology with another Post-colonial theological approach.

\title{
7.2 Tertullian and Africa in Historical Theology
}

One problem with classifying Tertullian as an "African Theologian" is the concept and perception of African Theology. ${ }^{15}$ In other words, when one

15 Or, even more broadly, African or Pan-African identity; see comments by V.Y. Mudimbe, "Race, Identity, Politics and History," Journal of African History 41 (2 2000), 291-4; Kwame Anthony Appiah, "African Identities," in Postcolonial Discourses: An Anthology, ed. Castle, 222-31; and Young, Postcolonialism, 217-8. 
mentions African Theology many, especially many from the West, envision a village south of the equator complete with rituals and customs unknown to the "Christian tradition." In recent decades, however, a theological challenge to much of the so-called "Christian tradition" - or more aptly, European Christian tradition - has come from contextual theologians such as those from Africa. ${ }^{16}$ In order for the reader to understand what is meant by African Theology and its import for Tertullian, a presentation will be given of this tradition, which even for many contemporary African theologians is normally described in postcolonial/sub-Saharan terms. ${ }^{17}$

\subsubsection{What constitutes African Theology?}

Christian scholars throughout history have recognized various theological "schools." Patristic theology, for example, has been divided between Greek and Latin theologies; countless other similar reifications constitute the progression of Christian thought throughout the centuries. ${ }^{18}$ The advent of indigenous African Theology has added another dimension to the study of Christian tradition and has created yet another voice in the practice of Christian theology. In determining any one "theology" the problem arises as to what distinguishes that specific theology from all other theologies.

Whether it is the Liberation theologies of Gustavo Gutiérrez and James $\mathrm{H}$. Cone, or the feminist theologies of Mary Daley and Rosemary Radford Ruether, two general elements constitute any one theology. ${ }^{19}$ The first is the historical context from which a specific theology arose; the Methodist Theology of John Wesley's followers drew from much different social, political and ecclesiastical

16 "Contextual" is used here reservedly because many so-called "contextual" theologians (liberation theologians, feminist theologians, etc.) adamantly argue that no theology is without context (i.e. contextual vs. "non-textual.") One could say that there are only two theological approaches: contextual theologians and theologians who do not admit to being contextual theologians.

17 In defining African Theology, Gwinyai H. Muzorewa, The Origins and Development of African Theology, (Maryknoll, NY; Orbis Books, 1985), 1, explains, "This task needs to be done because the church in Africa south of the Sahara is concerned about its self-identity in the postcolonial era." Other examples include Benezet Bujo, African Theology in its Social Context, trans. John O'Donohue, (Maryknoll, NY: Orbis Books, 1992), 58; and Robert J. Schreiter, "Foreword" in Bujo, African Theology, 1. Two examples of African theologians who give some mention to pre-colonial African Theology are Kwesi A. Dickson, Theology in Africa (Maryknoll, NY: Orbis Books, 1984), 1; and Rosini Gibellini, "Introduction," ed. Gibellini, Paths of African Theology, (Maryknoll, NY: Orbis Books, 1994), 1.

18 e.g. Altaner, Patrology, vi-vii, who divides the "Western Authors" from "The Authors of the Greek East."

19 Gutiérez, A Theology of Liberation, (London: SCM, [1971]1988); Cone, A Black Theology of Liberation, (Philadelphia: J.B. Lippincott Company, 1970); Daly, The Church and the Second Sex, (Boston: Beacon Press, 1968); Ruether, "The Liberation of Christology from Patriarchy," Religion and Intellectual Life 3 (1985): 116-128. 
sources than the Reform theology of John Calvin's disciples. ${ }^{20}$ The second element one considers is the response of the theologian to his or her context as with the examples of Augustine's response Rome's collapse or Dietrich Bonhoeffer's responses to the Nazi regime. ${ }^{21}$ Within the specific reaction to a specific situation, a new theological expression arises.

Because theologies can be constructed from a specific point in time as well as over entire historical periods, prescribing the context of "a theology" is difficult. An inherent tension exists, as between one slide of film and a complete motion picture or as between a measure of music and an entire arrangement. While authors appropriately write on the theology of the Reformers, there also exists $a$ theology of Martin Luther in $1517 .^{22}$ The existence of such a tension, however, in no way prohibits one from speaking of "a theology" spanning decades, if not centuries, that results from broad, sweeping movements and historical developments. The field of African Theology exists in such a tension today. ${ }^{23}$

For the sake of this discussion, African Theology needs describing in terms of its history, aim, methods and parameters. Common assumptions arise when the label "African Theology" is given to a specific work. Typically, the phrase evokes the post-colonial, sub-Saharan world sometimes known as "Black Africa." African theologians usually present their own history in such post-colonial terms, and therefore, the "beginnings" of African Theology as some recount it will be outlined below. Following a chronological presentation of African theological genesis, a survey of the overall direction and discussion of African theology, as stated by African theologians, will be presented

20 For Wesleyans, see George Smith, History of Wesleyan Methodism, vol. 1-2, (London: Longman, Brown, Green, Longman's and Roberts, 1857-8); J.S. Simon John Wesley and the Methodist Societies, (London: Epworth Press, 1937); and John Kent, Wesley and Wesleyans: Religion in Eighteenth-century Britain, (CUP, 2002). On Calvinists, see R.C. Gamble, ed., Calvinism in France, Netherlands, Scotland, and England (New York: Garland Publishers, 1992); Gamble, ed., Calvinism in Switzerland, Germany, and Hungary (New York: Garland Publishers, 1992); Andrew Pettegree, et al., eds., Calvinism in Europe: 1540-1620, (CUP, 1994).

21 Augustine, De ciuitate Dei; Bonhoeffer, Letters and Papers from Prison, ed. Eberhard Bethge, trans. Reginald Fuller, rev. Frank Clarke et al., (London: SCM, 1967).

22 cf. Timothy George, The Theology of the Reformers, (Nashville, TN: Broadman, 1988); and Kenneth Hagan, A Theology of Testament in the Young Luther: The Lectures on Hebrews, (Leiden: Brill, 1974).

23 Dickson, Theology, 2-3, elaborates, "Indeed, it has been suggested that Africa is more likely to produce theologies rather than a theology, given the great variety of religio-cultural, social and political realities in this vast continent... While uniformity of expression may not be expected or indeed be desirable, given the multifaceted nature of the African scene - we would think that there is much in the African situation which could bring about a considerable unity in theological expression." 


\subsubsection{The "Beginnings" of African Theology}

Although Christianity has existed in Africa since the earliest centuries of the Common Era and has survived in the forms of the Coptic (including the Ethiopian) churches, the narrative of the beginnings of African theology is set against the background of the European colonialism of recent centuries. Many indigenous Africans oppressed by European colonizers saw the "White man's" religion as an integral part of the colonial power structure. ${ }^{24}$ Many western missionaries sought to convert the "heathen," a process which included the conversion of language, dress and customs. As churches spread throughout the continent and as more and more Africans became a part of the imported Christian religion, the hierarchical structure of the clergy continued to reflect the colonial rather than the indigenous demographic. In reaction to the colonialism of both political and ecclesial settings, indigenous African Christians began to call for a critical review of their religion.

One of the first Africans who can be called an African theologian, according to Benezet Bujo, is Vincent Mulago. ${ }^{25}$ Born in what was then the Belgian Congo, Mulago became a Roman Catholic priest trained at the Urban University in Rome. He published two works in 1955 and 1956 that used African terminology and concepts to interpret liturgical practices. ${ }^{26}$ Other similar works followed by Africans who called for various reinterpretations and even adaptations of traditional theological concepts. ${ }^{27}$ One of the most influential of these was a paper published by several African priests in the Roman Catholic Church entitled, Des prêtres noirs s'interrogent. ${ }^{28}$ Robert J. Schreiter explains, "In that volume a group of young African theologians raised questions about how theology was being done in Africa and whether or not things could be different - both theologizing in a more genuinely African way and dealing with topics important to Africans." ${ }^{29}$ Specific questions about the traditional, that is European, understanding of theological concepts asked by these scholars preceded the fundamental question of theological approach that soon followed.

In 1960 the Revue du Clergé Africain published a report of the proceedings of a seminar held at the University of Lovanium in Kinshasa that sparked the debate over African theology. ${ }^{30}$ The discussion centered on the paper given by a student,

24 For the relationship between African theology and Pan-Africanism, see Muzorewa, The Origins, 3 and $46 \mathrm{ff}$.

25 African Theology, 58.

26 "L'union vitale Bantu, ou le principe de cohésion de la communauté chez les Bashi, les Banyarwanda et les Barundi," Annali lateranensi 20, (1956): 61-263; cited in Bujo, African Theology, 58 .

27 See Bujo, African Theology, 58.

28 Cited in A. Ngindu Mushete, "An Overview of African Theology," in Paths of African Theology, ed. Gibellini, 16.

29 Foreword to Benezet Bujo, African Theology, 1.

30 Revue du Clergé Africain 15 (1960), 332-52; cited in Bujo, 59. 
Tharcisse Tshibangu, entitled, "Vers une théologie de couleur Africaine?" Tshibangu called for an African church, led by African clergy, performing an African liturgy and producing an African theology.

The last aspect of Tshibangu's argument brought criticism from the dean of the Faculty of Catholic Theology in the University of Lovanium, Alfred Vanneste, in a paper entitled "D'Abord une vraie théologie." Vanneste argued that the task of theology is to aim for universal truth while the task of translating this truth into a palatable communication with indigenous individuals is left to the pastor and the missionary. Bujo comments on the debate: "Without entering into all the details of the discussion, it seems fair to say that Vannette's general position was authoritarian and unduly simplified the history of theology. Theological pluralism is after all perceptible even in the New Testament itself. ...Christianity has not grown up in a kind of culture-free vacuum but has always been in living dialogue with the surrounding culture." 31 The African clergy, and many faculty members of Lovanium reacted to Vanette's arguments with the same sentiments as Bujo, making Tshibangu the more widely accepted in theological opinion. ${ }^{32}$ Typified by this debate, a movement arose among indigenous African Christians to birth their own "Theology." In Africa, theology would not only be unique in its expression, but it would carry out a unique task.

\subsubsection{The Aim of African Theology}

Given the ethnocentric attitudes and actions of the colonial Christianity from which African theology arose, many African theologians readily set forth their agenda in terms of reaction and response. Speaking to the purpose of African Theology, Gwinyai Muzorewa states, "This task needs to be done because the church in Africa south of the Sahara is concerned about its self-identity in the postcolonial era." 33 Similarly, Benezet Bujo defines the purpose of African theology in terms of the context from which it arose: "Contemporary African theology arose out of the feeling of black people that they had not been taken sufficiently seriously by white people, including missionaries. African theology is a reaction." Many African clergy sensed that the "Theology" handed to them by the white Europeans was somehow insufficient to their African setting.

Christians in Africa have sought a theological system and language that communicates directly to their own social, political, environmental and ancestral milieus. African Christian thinkers proceed with their own approach to theology in order to address those needs. Charles Nyamiti explains, "Rightly understood, African theology comprises various definitions. In its broadest (etymological

31 African Theology, 62.

32 He was later appointed archbishop; see Mushete, "An Overview," 19.

33 Muzorewa, The Origins, 1.

34 Bujo, African Theology, 48. 
sense), African theology can be defined as discourse on God (theo-logos) - and on all that is related to Him - in accordance with the mentality and needs of the people in the black continent." ${ }^{35}$ The needs of the African Christians reacting to colonialism has provided a central locus in the advent of African Theology. However, as African Theology has developed, Christian thinkers have also broadened their understanding of the task of African Theology.

The task of creating a genuine African expression of Christianity, as opposed to a mere translation, has become a primary onus of African theology. ${ }^{36}$ In his introduction to Paths of African Theology, Rosino Gibellini explains how African theologians attempt to interact with "a Christianity that will be no longer imported or simply adapted, but authentically African, a Christianity lived and experienced against a horizon of Catholicity and ecumenicity amid the new concrete historical - cultural and social - dimensions of Africa." ${ }^{37}$ Aylward Shorter calls this "authentically" African Christian theology a theology of "Inculturation.",38 In his book, Shorter criticizes the established Church for adopting the dichotomized worldview of the ancient Romans - civilized/barbarian - and for the Church's unwillingness to recognize that every expression of Christianity is a temporal expression. ${ }^{39}$ Shorter also explains how African Theology, like South American Liberation Theology, understands the purpose of theology to be a concrete historical reflection, not an abstract system of propositions. ${ }^{40}$ Given the purpose of African Theology, African theologians proceed with a contextualized methodology.

\subsubsection{The Methods of African Theology - A Postcolonial Critique?}

One method that African theologians use to carry out their task is to underscore the Eurocentric approach to theology performed by many in the Christian tradition. Mushete attacks such an approach, claiming, "Universal theology is as mythical as universal philosophy. ${ }^{, 41}$ Shorter explains the methodology as found among African theologians: "As the centre of ecclesiastical gravity shifts inexorably from the North Atlantic to the Third World, this new, empirical understanding of culture is forcing a revision of Christian theology, Bible reading and Church history." ${ }^{42}$ Although African scholars use many theories and

\footnotetext{
35 "Contemporary African Christologies," in Paths of African Theology, 63.

36 For another task of African Theology, the understanding of God in traditional African religions, see Muzorewa, The Origins, 78.

37 Paths of African, 7.

38 Toward a Theology of Inculturation, (London: Geoffrey Chapman, 1988).

39 Ibid, 12 and 17.

40 Shorter, Toward, xi; cf. Gutiérrez, A Theology, 11.

41 "An Overview," 19.

42 Toward, xi.
} 
approaches, the rereading or reinterpreting of traditional Christian themes comprises a central endeavor of many African theologians.

Given the "decentering" terminology of African theology, the question arises as to the relationship between the disciplines of African Theology and Postcolonialism. A useful analogy can be drawn from Ashcroft, Griffiths and Tiffin who explain the complex relationship of postcolonial theories in the academic climate in the United States, a country the authors define as postcolonial:

Whilst the recent American critical models have been profoundly influenced by Europe, with Derridaian and Foucaultian theories being whole-heartedly adopted by American critics, the Americans are now beginning to recognize that their own postcoloniality had already provided the ground for similarly subversive views of language and culture. Rather than the postmodernists and poststructuralists being seen as decentring forces, undermining the categories of a universal authority, they are beginning to be viewed as confirmations of the essentially subversive nature of much American literature throughout its development: subversive, that is, of the authority of the European centre and its forms and expectations. ${ }^{43}$

The example of literary criticism in the United States provides a possible analogy for explaining the relationship of African Theology to Postcolonialism, both stemming from the common groundswell of dissatisfaction of Eurocentric claims to "universal" knowledge and truth. ${ }^{44}$

\subsubsection{The Parameters of African Theology}

Although one approach of African Theology reinterprets Christian tradition, including Christian history, one area of tension for African Theology is the development of the post-colonial expression of Christianity within the entire spatio-temporal reality of Africa. More specifically, a question that needs to be addressed is, "What is post-colonial/sub-Saharan African theology's relationship with pre-colonial/pan-African Christianity?" Or, in other words, one could ask: "What has Alexandria to do with Johannesburg?"45 Because African theology largely developed out of the colonial experience, the initial focus for many African theologians needed to be limited. Nevertheless, the question of the limits and boundaries of African theology has always been present within African theological discussions.

\footnotetext{
43 The Empire, 163.

44 See Young, Postcolonialism, 64, for the "refusal of totalizing forms"; also, Castle, Postcolonial Discourses, xv.

45 cf. Tertullian, De praes. haer. 7, "What indeed has Athens to do with Jerusalem?" [Quid ergo Athenis et Hierosolymis?]
} 
A few examples of African theologians who have addressed the parameters of African Theology will help clarify the spatio-temporal tension that exists. Kwesi A. Dickson reports on a discussion spawned by a paper he presented at the 1973 meeting of the Faith and Order Commission of the World Council of Churches. A European priest objected to the claim that Africa needed a unique theology, arguing that such a course of action threatened the unity of the ecumenical Church. Dickson explains,

If he had not been so agitated, he might have noticed and commented upon the fact that the Africans in the study group were not by any means unanimous regarding the shape which Christianity in Africa should take. An Ethiopian participant, for example, was somewhat irritated by the talk of Christianity taking account of African culture: had not the Coptic church already done that? Indeed, in my judgement the explosive situation in the discussion arose, not so much from what the African participants thought of European Christianity as from what the African Christians, coming as they did from a variety of Christian traditions, considered to be the way forward for the Church in Africa, ${ }^{46}$

Although Dickson argues that "there is much in the African situation which could bring about a considerable unity in theological expression," he recognized the suggestion that Africa "is more likely to produce theologies rather than a theology, given the great variety of religio-cultural, social and political realities in this vast continent. ${ }^{47}$ The Coptic/Ethiopian tradition has kept Christianity vital in certain parts of the African continent, and Dickson acknowledges that there is room in African Theology for multiple voices.

An example that provides insight into the temporal tension within African Theology is a statement made by Gwinyai Muzorewa. In discussing both the importation and the importance of the Bible in Africa, he reflects on the chronology of African Christianity, "Most African theologians see the presence of Christianity in Africa in three stages: the infant Jesus as a refugee in Egypt; Christianity in Africa under the Portuguese prowess of the fifteenth to the seventeenth century; and, finally the dramatic nineteenth-century awakening." 48 Because of the specific aim of Muzorewa's argument, his oversight of the Ethiopian, the Coptic, and even patristic churches need not be criticized here. The statement highlights, however, the lack of attention given to these traditions by contemporary African theologians.

Although African theologians, working within the specific aims of their field, focus on the post-colonial expression of Christianity out of necessity, they do not intentionally forsake previous traditions of Christian communities on the African continent. Rosino Gibellini begins the work he edited on African Theology by highlighting the history of Christianity in Africa, including the era of the Church

46 Dickson, Theology in Africa, 1.

47 Ibid, 2-3.

48 The Origins, 22 
fathers. ${ }^{49}$ Some African theologians have even called outright for an inclusion of early Christian history in African theology. One example is Bujo when he says, "Our guide in the construction of theology must be, apart from African tradition, the Bible and the Fathers of the Church. They must be the light which will show up the limitations and the inadequacies of any theological system, however brilliant." 50 Bujo represents some African theologians who consciously recognize the wider reality of African Theology. ${ }^{51}$ In accordance with Bujo's plea, it is suggested here that Tertullian, the first "Latin" Christian writer, can also belong within such a broad understanding of African Theology. ${ }^{52}$

\subsubsection{Is Tertullian an African Theologian?}

Tertullian's contribution as a theologian needs no defense. ${ }^{53}$ He is, in fact, often called "The Father of Latin Theology," but one could - controversially - claim this widely used title, which traces back even to Jerome, to be yet another example of a Eurocentric approach to theology. ${ }^{54}$ Analogously, few - if any would credit the Apostle Paul with the title, "The Father of Greek Theology," simply because he was the first Christian thinker to write in Greek. Paul has not received such a distinction because of his own testimony that he was first,

49 Paths of African Theology, $1 \mathrm{ff}$.

50 African Theology, 68.

51 cf. discussions among postcolonial critics, such as Gregory, Postcolonial Discourses, xv, regarding the tension between the regional characteristics of postcolonial writers and the "common elements transcending regional difference."

52 cf. Kwame Bediako, Theology and Identity: The Impact of Culture upon Christian Thought in the Second Century and in Modern Africa, (Oxford: Regnum Books, 1992), who juxtaposes Tertullian and other early Christian writers with post-colonial counterparts, arguing that both elevate the Christian religious identity above even regional ones, and thereby largely ignoring Tertullian's African-ness in lieu of his "Graeco-Roman culture" (esp. 7 and 107); however, A. Okechukwu Ogbonnaya, On Communitarian Divinity: An African Interpretation of the Trinity, (New York: Paragon House, 1994), interprets Tertullian's theology as explicitly "African”; for another approach, René Braun, "Aux origines de la Chrétienté d'Afrique: un Homme de combat, Tertullien," Bulletin de l'Association Guillaume Budé, (1965): 189-208, also understood Tertullian as "la Chrétienté africaine" (189), that is, "origine punique... aux Africains berberes" (194), which, for Braun, is evidenced by many negative traits such as "le dédain de l'intellectualité" (203) and even "fougue" and "violence" (208).

53 Jean Daniélou, The Origins of Early Christianity [Histoire des doctrines chrétiennes avant Nicée], vol. 3: "The Origins of Latin Christianity" ["Les origines du christianisme Latin"], trans. David Smith and John Austin Baker, ed. and postscript John Austin Baker, (London : Darton, Longman and Todd, 1977), 340. However, Dunn, Tertullian, 35, clarifies that Tertullian is not a "systematic theologian."

54 For examples of Tertullian's title see S.L. Greenslade, Early Latin Theology: Selections from Tertullian, Cyprian, Ambrose, and Jerome, (London: SCM Press, 1956), 23; and similarly Eric Osborn, Tertullian, First Theologian of the West, (CUP, 1997). Jerome, De uiris illustribus 53.1: demum primus post Victorem et Appollonium Latinorum ponitur. 


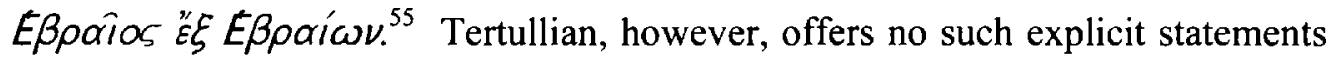
of self-identity, a fact that allows the Roman, the European or the Westerner to read Tertullian as a Roman, a European or a Westerner with relative ease. ${ }^{56}$

Tertullian's influence over Western Theology does not negate his original context which had non-western aspects. ${ }^{57}$ Tertullian was from the Province of Africa and was therefore - at least by one taxonomy - an African. ${ }^{58}$ While the temptation to anachronistically compare Tertullian's "African Theology" with more recent sub-Saharan, post-colonial "African theology" could be viewed as precarious, such an approach could prove no more amiss than the traditional approach - conscious or otherwise - of reading Tertullian as a European. Instead, the juxtaposition of a competing branch of theology from the same continent as Tertullian provides a different framework that might better appreciate certain aspects of Tertullian's self-identity and theology. ${ }^{59}$

Should not scholars read Tertullian as neither a European nor an African but simply in light of his own writings? Many from a Postcolonial context would declare that this objection - rather, this modernist claim to objectivity - could only be made by a westerner, because those the "centre" has labeled the "peripheral" know that to read Tertullian "objectively" is impossible, and any attempt to do so will likely neglect an appreciation for his African-ness. With this objection in mind, the more pertinent question is, "What does it mean to be an 'African' during Roman colonization of Africa?" a discussion which the previous chapters have hopefully helped to facilitate.

African theologians, as shown above, often invoke early Christian authorities with African associations. In doing so, African theologians can be accused of misappropriating those sources in order to legitimize their own endeavors - as can any claim to the past. ${ }^{60}$ Moreover, historians can claim that such a practice is anachronistic and invalid, given that the African context of the early Christian centuries was in fact part of the wider so-called "Graeco-Roman culture." While

55 Philippians 3:5.

56 e.g. von Campenhausen, Fathers, 20, “...Tertullian was a Westerner...."

57 For example, the argument of some scholars that Tertullian, who wrote some tracts in Greek, is part of the Second Sophistic movement; see Barnes, Tertullian, 211; on the Second Sophistic movement more generally, see Simon Goldhill, ed,, Being Greek under Rome. See also, Bediako, Theology, 117, who criticizes Daniélou's identification of Tertullian as exclusively "Latin" and not "African."

58 von Campenhausen, Fathers, 5, "Tertullian was an African, i.e. a citizen of Africa, the province colonized by the Romans, which is modern Tunisia."

59 Bediako, Theology, xii, claimed this would allow one "...to read the Christian Fathers in their contexts with new eyes!" Similarly, Denise Kimber Buell, "Rethinking the Relevance of Race for Early Christian Self-Definition," HTR 94 (4 2001), 474, argues, "Mainstream theology and historical scholarship on Christianity have much to gain from the challenges and visions offered by voices marginalized by ideology and/or social location."

60 e.g. Ogbu U. Kalu, "The Golden Age of Christianity in Africa?: Early Christianity in North Africa Revisited," Nsukka Journal of Religious Studies, 1 (1 1996), 34, refers to "romantic efforts." 
both of these accusations can be adequately dealt with by African theologians independently from this study, it is hoped that the above discussion has opened fresh avenues for dialogue in this area by deconstructing the notion of a "GraecoRoman culture" - which can be a pseudonym for early "Western civilization" and by destabilizing what constitutes "Africa" to allow for a broader spatiotemporal referent while acknowledging the diversity inherent therein. Likewise, in the field of African Theology, the genesis and origins of Christianity on the African continent are just as important for a more complete and holistic picture of the heritage to which African Christians, let alone others, have a claim.

Overall, this project has cut across many traditional fields of inquiry and incorporates insights from multiple academic disciplines. It is hoped that they have all appropriately and coherently intersected in the exploration of the writings, theology and identities of the early Chrsitian writer, Tertullian the African. 
